\title{
Sağlıkta Dönüşüm ve Direnme Pratikleri: Tuzluçayır Halk Sağlığı Günleri
}

\author{
Ceylan Nur Akgün**
}

Öz

Mamak, Tuzluçayır bölgesinde gerçekleştirilen bu etnografik çalışmada, sağılı sisteminde yaşanan neoliberal dönüşümün yerel ve mikro ölçekteki tezahürleri araştıııımışıı. Halkevlerine gelen ve bu mekanla ilişkilenen kadın ve erkeklerin deneyimleri üzerinden neoliberal sağlık söyleminin yansımaları izlenmiştir. Halkevleri çevresinde örgütlenen ücretsiz sağlık hizmeti çalışmaları, iktidarın biyopolitik rejimine alternatif olarak üretilen yeni çözüm taktikleri, direnme ve dayanışma deneyimleri olarak değerlendirilmiştir. Sağlık hizmetlerinin giderek piyasaya tabi olması ve büyüyen "sağıklı olma söylemi"ne karşın, yerel örgütlerin hekimler ve sağlık personeliyle işbirliğine girerek ücretsiz halk sağlı̆̆ı eğitimleri yaptığı uygulamalar başlıbaşına iktidarın sağlık alanındaki stratejilerine karşı bir tür taktik ya da mikrodireniş olarak düşünülmüştür. Çalışma, etnografik yöntemlere yaslanarak halkevleri ile ilişkilenen Tuzluçayır sakinlerinin sağlık sistemini nasıl ele aldıklarını ve onunla nasıl ilişkilendikleri anlamak üzere geliştirilmiştir. Ergenlik dönemi psikolojisi, cinsiyetler arası rol paylaşımı, ebeveynlik tutumlarılla ilgili yapılan psikoeğitimler sırasında iktidar ile kolektif kimlikler ilişkisinde her an müzakere edilen, direnme ve teslim olma arasında gidip gelen ilişkinin yansımaları izlenmiştir. Biyopolitik söylemin izlerini sürmek amacıyla başlayan bu saha deneyimi, her yerde olan ve herkesi denetleyebilen iktidara rağmen, düşünen, eyleyen ve direnen öznelerin özgürleşme kapasitesini de gösterir. Tuzluçayır Halkevi, sistem içinde çözüm arayıp eli boş dönenlerin sorunlarını çözmeye çalışan yerel ve mikro ölçekte kurulan bir oluşum olarak hem bir dayanışma hem de direniş, mücadele hattı olarak değerlendirilebilir.

Anahtar Sözcükler: Sağlık iletişimi, tıp söylemi, biyopolitika, ergenlik, neoliberal sağlık politikaları.

\footnotetext{
* Geliş tarihi: 09/07/2019 • Kabul tarihi: 03/11/2019

${ }^{*}$ Hacettepe Üniversitesi Sosyal Bilimler Enstitüsü Illetişim Bilimleri Doktora Programı

Orcid no: 0000-0002-1989-9699, cnakgun@hotmail.com
} 


\title{
Transformation in Healthcare System and Practices of Resistance: Tuzluçayır Public Health Days*
}

\author{
Ceylan Nur Akgün **
}

\begin{abstract}
In this ethnographic study which is done in Tuzluçayır district of Mamak, local and micro-scale manifestations of neoliberal transformation in healthcare system is observed. The reflections of neoliberal healthcare discourse were monitored through the experiences of men and women who comes to and interacts with community centers. Free of charge healthcare services, new solution tactics generated as an alternative to the government's biopolitical regime were evaluated as resistance and solidarity experiences. Although healthcare services are increasingly dependent upon the market and despite the growing discourse on "being healthy", the free-of-charge public health training practices of local organizations in cooperation with physicians and healthcare personnel were considered to be a kind of tactic or micro-resistance against the healthcare strategies of the government. Taking ethnographical methods as a basis, this study was made to find out how the residents of Tuzluçayır who have connections with community centers approach to the healthcare system and how they interact with the system. During the psycho-trainings on adolescence psychology, inter-gender role division and parental attitude, the reflections of the relationship which was discussed in the relations between the government and collective identities and which alternates between resistance and surrender were monitored. This field experience aiming at tracing the biopolitic discourse also demonstrates the capacity of liberation of the subject who thinks, acts and resists despite the power, which is everywhere and can control anyone. Tuzlacayir Community Centre being an entity establised locally at micro level, trying to solve the problems of those who have attempted to seek resolution within the system but have returned empty handed, may be evaluated as a network of solidarity as well as ra network of resistance.
\end{abstract}

Keywords: Healthcare communication, healthcare discourse, biopolitics, adolescence, neoliberal healthcare policies.

\footnotetext{
* Received: 09/07/2019 - Accepted: 03/11/2019

${ }^{* *}$ Hacettepe University Institute of Social Sciences Communication Sciences Doctoral Program

Orcid id: 0000-0002-1989-9699, cnakgun@hotmail.com
} 


\section{Sağlıkta Dönüşüm ve Direnme Pratikleri: Tuzluçayır Halk Sağlığı Günleri}

Bu çalışmada, sektörleşen ve giderek piyasa düzenine eklemlenen sağlık sisteminin gündelik hayat içindeki yansımalarını izlemeyi amaçladım. Mamak Tuzluçayır Halkevleri'nde gerçekleşen sağlık eğitimleri programının bir parçası olan; "Ergenliğin ön plana çıkan sorunları" konulu eğitimlerde görev aldım. Tuzluçayır bir Alevi bölgesi ve sol hareketin Ankara'daki kalesi olarak bilinen bir semt (Yürekli, 2016: 51; Sofracıoğlu 2005: 209). Farklı marjinalleşme ve aidiyet düzenlemeleriyle ön plana çıkan bölgede hem dini olarak hem de ideolojik olarak ötekileşen Alevi ve sosyalist bir azınlıktan bahsedebiliriz (Yürekli, 2016: 151-162). 1970'lerden itibaren halk arasında "Küçük Moskova" olarak adlandırılan bölgede halen sol geleneğin izleri görülmekte (Sofracıoğulları, 2005). Araştırma sahasının Tuzluçayır olarak seçilmesinde, halk sağlığı eğitimleriyle ilgili talebin bu bölgeden sıklıkla gelmesi belirleyici oldu. Halkevi sorumlularının mahalle sakinlerinin kültürel, sosyal, eğitici etkinliklere düzenli katılım sağladığını belirtmesi bölgenin seçilmesindeki bir diğer etkendi. Ankara Tabip Odası ve Halkevlerinin beraber organize ettiği ve tüm yıla yayılacak olan bu programda, sağlık konularına ilgi çekmek, doğru ve güvenilir bilgiyi ücretsiz olarak halka ulaştırmak ve mümkünse tedavi olanakları oluşturmak amaçlandı.

Programın konu başlıklarını belirlemek üzere Ağustos 2016'da Halkevleri genel merkezinde yaptığımız toplantılarda, bölge halkının taleplerine göre sunumların belirlenmesi kararlaştırıldı. Halkevi gönüllüleri yaptıkları saha araştırmasından sonra; stresle başetme, üreme sağlığı ve kadın cinselliği, çocuk ve ergen gelişimi, sağlıklı beslenme, günümüzde anne-babalık ve çocuklarla ilişkiler gibi konu başlıklarına talebin fazla olduğunu belirtti. Talep edilen konu başlıkları, sağlıklı olma mefhumunun, artık hasta, hastalık, hastane sınırlarının dışına çıkarak tüm insan yaşamına yayılmış olduğunu düşündürtmekteydi.

Etnografi, nitel araştırma geleneğinin en eski yöntemidir (Patton, 2002: 81). Günümüzde de birçok disiplinde kullanılan etnografik yöntem (Merriam, 2015: 27) belirli mikro bir grubun sistematik olarak incelenmesi sürecini içerir. Etnografik çalışmalarda, ortak kültüre sahip bir grubun paylaştığı değerler, davranışlar, inançlar nitel olarak tanımlanıp yorumlanır (Creswell, 2016: 9). Araştırmacı sahada olur ve 
araştırdığı grubun anlam dünyasını, yaşamlarını nasıl yönlendirdiklerini keşfetmeye çalışır (Emerson ve ark, 2008: 2). Çalışmama veri sağlayan süreç, Ankara Tabib Odası ve Halkevlerinin ortaklaşa gerçekleştirdikleri programın Kasım 2016-Şubat 2017 tarihleri arasındaki bölümünde elde edildi. Ben, çocuk ve ergen psikoloğu olarak bu çalışmanın hem eğitimcisi hem de gözlemcisi konumunda yer alarak, Tuzluçayır Halkevine düzenli olarak gelen insanları gündelik yaşamları içinde -Emerson'un deyimiyle bir tür "içe dalış" deneyimi ile- (2008: 1) aktarmaya çalışım. Eğitim süreçlerinden sonra, altı katılımcıyla derinlemesine görüşme yapma olanağım oldu. Görüşmecilerin dördü eğitimlere devam eden mahalle sakinleriydi. Diğer ikisi ise Halkevinde gönüllü çalışmalar yapan Sevgi ${ }^{1}$ ve Aynur ${ }^{2}$ idi. Dolayısıyla bu makale bir yandan kendi gözlemlerime diğer yandan da bu görüşmelerden elde ettiğim verilere dayanmakta.

\section{Neoliberalizm ve Sağlık Politikaları}

Foucault (2002: 171), kliniklerin hastaların tedavisini amaçlar gibi görünse de aslında modern toplumların disipline edici, ıslah edici, denetleyici tekniklerinin uygulamaya geçtiği yerler olduğunu söyler. Tıbbın normları, üretken, çalışkan, uyumlu ve itaatkâr insan modeliyle uyumludur. 17. yüzyıldan itibaren kendine gönderme yaparak oluşan bir tıbbi söylem giderek kendi varlığını meşru hale getirir, sorgulanamaz bir hal alır ve iktidarını kurar (Foucault, 2002: 170-175). Bu süreçte, hastanın yerini patoloji almakta, hastalanan kişiler birer "vaka" haline gelerek bedenleri nesneleşmektedir. Modernizmle birlikte tıbbın öznesi hastanın kendisinden hastalığa doğru evrilmiş; iktidarın paradigması, öldürme yetkisinden yaşatma iradesine olacak şekilde değişmiştir. Bundan sonra iktidarın ilgisi yaşamın biyolojik yapısına ve potansiyellerine yönelmiş, baskıcı unsurların yerini düzenleyici, üretken ve olumlayıcı pratikler almıştır. Nüfusun üretken ve uyumlu yaşamına odaklı biyoiktidar, tüm mekanizmalar, kurumlar ve söylemlerle yaşamı düzenlemek üzere seferber olur. Disiplin ve gözetimin yerine

\footnotetext{
1 Çalışmada yer alan bütün isimler değiştirilmiştir. Sevgi, Tuzluçayır'da özel bir okulda öğretmenlik yapıyor. Doğma büyüme Mamaklı olduğunu ve bu semtten ayrılmak istemediğini söylüyor. Sevgi, üniversite mezunu, 32 yaşında, eşi ve annesi ile birlikte Tuzluçayır'da yaşıyor. İş dışında tüm zamanını "halkevciliğe ve devrimciliğe adadığını" söylüyor.

2 Aynur, 24 yaşında, üniversite mezunu, özel bir dershanede öğretmenlik yapıyor ve bekar. Halkevlerinde gönüllü eğitimler veriyor ve özellikle kadınlarla ilgili bilinçlendirme çalışmalarını yürütüyor.
} 
düzenleme ve denetimin gelmesi, doğal ile yapay, normal ile anormal, hayat ile ölüm, kültür ile doğa ya da somut ile soyut arasındaki sınırların çizilmesi, kuralların, normların, ideallerin belirlenmesiyle gelişen bir süreçtir (Foucault, 2005).

Modern kapitalist sistemde, teknik bir biçimde işleyen ağ tipi bir yönetimsellik vardır ve birbirinden çok farklı alanlarda -hastaneler, okullar, üniversiteler, profesyonel gruplar, aile gibi- hayatın her noktasına müdahale eder, düzenler ve benzer normları kurmaya çalışır (Koyuncu, 2016: 21-61). Nitekim, bu yönetimsellik ağı içinde kurulu bioiktidar mekanizmaları neoliberal dönemle birlikte daha belirginleşir. 1980 sonrası, kamu hizmetlerinin yapısı değişmeye başlar. Önceden kamusal olan sağlık hizmetleri, verimlilik bahanesiyle hızla özelleştirilir, sağlık harcamaları devlet bütçesine yük görülerek kısıtlanır. Kamusal sağlık hizmetleri, hastalıkların sağaltımına ek olarak; çevre sağlığı, temiz içme suyu sağlanması, salgınlara karşı koruma, aşılama kampanyaları, yaşlıların bakım ve rahabilitasyonu gibi pek çok alanı içermektedir. Neoliberal politikalarla birlikte bu alanlar devletlerin sorumluluğundan çıkarılıp özel sektöre devredilir.

Sağlıkta böyle bir özelleşme problemlidir çünkü; piyasaya sunulan bir malın tüketilip tüketilmemesi bireyin insiyatifinde olabilirken sağlık için böyle bir tercih özgürlüğü söz konusu olamaz. Kişi, hastalanıp hastalanmayacağını kontrol edemez, hasta ise tedavi olmak zorundadır ve hangi tedaviyi ne şekilde ve nereden alacağını belirleyemez (Illich, 2014: 48-54). Neoliberal sağlık sisteminde en iyi hasta, sağlık hizmetlerine en çok para ödeyebilen olarak algılanır (Deppe, 2011: 43-53). Türkiye'de sağlığın sektörleşmesi dünyadaki modelleri takip etmiştir. Kamu sağlık harcamalarının yüksek maliyeti ve verilen kamu hizmetinin düşük nitelikli olduğu gerekçeleriyle devletin sağlık hizmetinden çekildiği ve tüm sağlık alanının piyasaya açıldığı bir süreci izleyebiliriz (Ergül, 2009: 25): Sağlıkta Dönüşüm Projesi kapsamında uygulanmaya başlayan programlarla, sistemin yapısında büyük değişiklikler gerçekleştirilir. Bu değişiklikler tüm vatandaşları tek bir sosyal güvenlik fonu altında birleştiren genel sağlık sigortası, performans sistemi, yeni personel istihdamı ve aile hekimliğinde sözleşmeli statüde personel alımı, kamu sağlık ünitelerinin özerk işletmeler haline dönüştürülmesi, katkı payı ve fark ücreti uygulamasıyla sağlık hizmetinin karşılanmasında vatandaşın doğrudan kaynak haline gelmesi ve özel sektörün sağlık hizmeti sunumundaki payının arttırılması olarak özetlenebilir. Tedavi için başvuran 
hastalardan "katkı payı" adı altında ücret alınması, özel sağlık kurumlarının sayısını hızla artırmış fakat özel kurumların verdiği hizmetin niteliğini tartışmalı hale getirmiştir (Elbek ve Adaş, 2009: 37). Kamu bütçesinden sağlığa ayrılan kaynakların özel sağlık kurumlarına aktarılması hasta başına düşen personelin azaltılmasına, iş bölümünün derinleştirilerek emeğin ucuzlamasına neden olmaktadır (Sönmez, 2011: 30-69). Sağlıkta dönüşümün önemli bir basamağı da, aile hekimliği uygulamasıdır. Aile hekimliği, uzmanların rekabet mantığı ve hasta kaybetmeme kaygısıyla çalışmalarına yol açmaktadır (Elbek ve Adaş, 2009: 36). Uygulamanın en problemli görülen yanı ise birey ve halk sağlığını ayrıştırıyor olmasıdır. Aile hekimliği uygulamasının ardından verem savaş dispanserleri, ana çocuk sağlığı merkezleri gibi koruyucu tıp birimleri ve halk sağlığı üniteleri israfa yol açan kurumlar olarak görülerek kapatılmıştır (Elbek ve Adaş, 2009: 35-36). Hekimlik mesleğini doğrudan hizmet sektörü içinde konumlandıran ve fiili kârın paylaşılması üzerine örgütlenen performans sistemi hekim ile hastanın birlikte geçirdiği zamanı azaltıp sağlık hizmetinin kalitesini düşürmekte, sağlık personelinin niceliksel iş yükünü artırmaktadır (Ergül, 2009: 24-25). Bu sistem nedeniyle hekimler ve hastane yönetimleri tedavisi zor ve riskli hastalıklardan kaçınmaya, kârlılığı yüksek olan küçük cerrahi uygulamalara ve tetkiklere yönelmeye başlamaktadır (Hamzaoğlu, 2011: 22-25). Böylece gereksiz tetkik ve tedavilerin sayısı artarken kronik ve ağır hastalıkların tedavisi zorlaşmaktadır (Hamzaoğlu, 2011: 22-25).

\section{"Sağlıklı Yaşam" İstilası}

Bugün içinde yaşadığımız sosyal/kültürel ortam, hayatın nerede başlayıp bittiğini, nasıl yaşanacağını, yaşamın koşullarını ve hedeflerini belirleme üzerinde söz sahibidir. Özellikle tıp ve sağlık alanındaki söylem, yaşamın içinde gün geçtikçe daha fazla yer kaplamakta, hayatın kendisi "sağlıklı yaşama" misyonuna dönmektedir. Tıbbın güvenirliğini ve bilimin iktidarını arkasına alan bu söylem sıradan insanların yaşamlarını kontroller, check-uplar, kan testleri, diyet, organik beslenme, egzersizler ve hormon ölçümleriyle doldururken, sağlıksız olduğu düşünülenler kaygı uyandırmaktadır (Delibaş, 2013: 105-108). Birbiriyle tutarsız uyarıcı bombardımanı altında (televizyondaki sağlık programları, farklı hekimlerin farklı yaklaşımları, yeni tanılar, magazin, sağlık dergileri ve sosyal medya) "sağlıklı yaşama" söyleminin varlığından bahsedebiliriz. Yiyecekten giyeceğe, ev eşyalarından (halılar, duvar 
kağıtları, yataklar vb.) kozmetiğe kadar tüketime sunulan hemen her şeyin üzerinde "sağlıkı" olduğunu vurgulayan bir ibareye rastlamaktayız. Gündelik dili istila eden sağlıklı yaşam söylemi ve inşa edilen sağlıklı beden kavrayışı "hasta olmama hali"nin çok daha ötesinde, bireylerden her an teyakkuz halinde olmayı talep etmektedir. Çünkü vücudumuza girmeye çalışan mikroplardan, bedenimize sızacak olan kanserojen maddelerden, şekerden, yağdan, tuzdan ve daha nice elementten oluşan listeden haberdar olmamızı, bu maddelerin etkilerini ve korunma yöntemlerini bilmemizi vaz eden bir hakikat yasası işlemektedir. Bu yasa, sağlıklı kalma yükümlülüğünü kişinin sırtına yükleyen bireyci ekonomik/politik yapılanmaların bir ürünüdür (Sezgin, 2011: 80). Hasta olduysanız kendi mesuliyetlerinizi yerine getiremediğinizle ilgili imalar hatta bazen açıkça suçlamalara maruz kalmak alışıldık bir durumdur. Diyetinizi inmal ettiğiniz, yeterli egzersiz yapmadığınız, sigara içtiğiniz ya da kanınızdaki şekeri, kolesterolü ayarlayamadığınız için sorumluluğunuz vardır. Kişiyi kendi doktoru olma yolunda telkin eden, örneğin hastalığın semptomlarını fark etme ve doğru tedaviyi seçme işini bireye yükleyen sistem, hasta rolünü tüketici olarak değiştirir (Sezgin, 2011: 52-82). Devleşerek büyüyen bir sektör, mallarını tüketiciye seçmesi için arz eder. Medya da bu süreçte, sağlıklı kalabilmek için neler tüketilip neler yapılacağını söyler (Sezgin, 2011: 115-141). Büyüyen sağlıklı yaşam endüstrisi, sürekli artan sağlık maliyetleriyle piyasa lehine işler. Günümüzde artık sağlık hizmeti tüm kollarıyla piyasaya eklemlenerek, küresel kapitalizmin büyük kârlar elde ettiği bir sektör haline gelmiştir. Hastalar artık müşteridir. Farmasötik istila vitaminleri, kozmetik ürünleri, hormonlarıyla hasta olmayan bireyi de gelecekteki sağlıkları uğruna tedaviye davet eder (Illich, 2014: 48-54).

Diğer yandan, tüm bu bilgi akışı ve kirliliğine rağmen, hastalar tipik bir tüketici gibi seçme hakkına sahip değildir. Sağlığın tüketimi düzensiz ve belirsizdir, çünkü kişiler hekimi gördüklerinde hastalıklarının adını, tedavilerinin ne şekilde olacağını ve maliyetini bilemezler. Sağlığa olan talep istekten değil intiyaçtan doğduğu için sağlığı diğer metalar gibi değerlendirmemek gerekir. Hastaya bilgi akışı çok olsa bile tanıya ve hangi tetkikin uygulanacağına hekim karar verir. Talebi, hizmet sunucu olan sektör ve sözcüleri olan hekimler belirler. Sağlıklı yaşamakla ilgili söylemin bu denli artışına karşın sağlık hizmetlerine ulaşımda, devlet bütçesinden sosyal sigortalara ayrılan fonlarda, devlet hastanelerinin kalitesi ve kapasitesinde, kamu sigortalarının 
karşıladığı tedavi masraflarında benzer bir artış görülmemektedir (Ercan, 2013: 1027). Sağlık söylemi, tüketim ve rekabet mantığı altında tüm yaşam tarzını düzenleyen kurumlar, uygulamalar ve pratikler sistemi haline gelmekte, sektörleşme kişilerde aldıkları hizmetin kalitesi ve gerekliliği konusunda kaygı yaratmaktadır.

Bu çalışmada ele alınan halk sağlığı faaliyeti, yukarıda bahsedilen neoliberal sağlık politikalarına karşı bir alternatif oluşturma çabası olarak ele alınabilir. Günümüzde hakim olan bireyselleştirilmiş sağlık anlayışına karşın, halkevlerinde yapılan çalışmalar, tutarlı ve uzmandan alınan güvenilir bilgiye ücretsiz ulaşabilme imkanı yaratmaktadır. Bundan sonraki kısımda, halkevleri hakkında kısa bir bilgi verilip, ardından halkevleri ve Ankara Tabip Odasının birlikte yürüttüğü eğitimlerin işleyiş şekli analiz edilecektir.

\section{Halkevleri ve Halkevleri'nin Sağlık Çalışmaları}

Cumhuriyet tarihinin en devamlı politik örgütlenmelerinden biri olan Halkevleri kurulduğu 1932 yılından 1950'lere kadar devam eden ilk yıllarında, dönemin Türkiye'sinin "talim ve terbiye kurumu" olarak değerlendirilir (Yeşilkaya, 2003). Kurum, Kemalist Cumhuriyet ilkelerine göre medeni bir yaşam tarzı inşa etmek üzere, eğitim, sanat, spor alanlarında organize olarak resmi ideolojiyi (1932-50) topluma yayma işlevi üstlenir. Kemalist rejimin topluma benimsetilmesi için bir propoganda örgütü olarak çalışan Halkevleri, Kemalist rejimin öngördüğü ilkelerin uygulama mekanları olan ideolojik araçlar olarak değerlendirilir (Karaaslan, 2003: 181). Bu sebeple örgütün işleyişi, rejimin yaratmaya çalıştığı ortamla sınırlı kalmakta ve rejimin izin verdiği kadar demokratik olabilmektedir (Karaaslan, 2003: 181). Halkevleri yeniden açıldıkları 1963 'de, yeni amaçlar ve politikalarla kendini yeniden örgütlemeye çalışır. İlk yıllarında kullandığı söylemler 1968 toplumsal hareketleriye birlikte değişmeye başlar. İlk yıllarındaki Kemalist söylemin yerini devrimci, halkçı ve antiemperyalist bir söylem alır (Karaaslan, 2003: 183). 1980’lere kadar sürecek olan bu çizgi halkevlerini sol harekete yaklaştırır. Bu yakınlaşma, merkez yönetimlerce halkevlerinin tepki görmesine ve çalışmalarının engellenmesine yol açar ve nihayet 12 Eylül 1980 Darbesi sonrasında kurum kapatılır. Halkevleri son olarak 1987'de tekrar açılır. Üçüncü döneminde örgüt yeni sol - yeni toplumsal hareketler çizgisine yaklaşarak, "kitle temelli bir çalışma modelini oluşturan demokratik kitle örgütü modeli”ne yakın durur (Karaslan, 2003: 
185). Özellikle AKP iktidarı sonrası, devlet ideolojisinde gerçekleşen paradigmik değişimle beraber Halkevleri'nin, devlete ve iktidara daha muhalif bir konuma geçtiği, laiklik ve özgürlük vurgusunun arttığı, sosyalist kodları her zamankinden daha çok kullandığını düşünebiliriz. Kamusal ortamda piyasa ilişkilerinin dışında durmaya çalışarak, karşılıklı dayanışma, yardımlaşma, eşitler arası ilişki gibi ilkelerle toplumsal hayatın yeniden örgütlenmesini amaçlayan örgüt, yoksul halk için ulaşılması zor bir hizmet haline getirilmiş olan sağlık ve eğitimin temel bir hak olması yönünde çalışmalarını sürdürmekte.

Gönüllülerden biri olan Seher ${ }^{3}$ ile yaptığım mülakatta halkevlerinde yapılan çalışmalarda yerelliğin her fırsatta vurgulandığı dikkatimi çekti. Seher, temsil yetkisininin kaynağını işaret etmek üzere sıklıkla "mahalleye gitmek, mahalleye sormak" gibi ifadelere başvurdu. Seher'den alınan bilgilere göre, kadın, sağlık, eğitim ve çocuk gibi konularda oluşturdukları meclisler var. Meclisler ve halkevci gençlerden oluşan ekipler kahveleri, esnafı, ibadet yerlerini ve haneleri dolaşıp talepleri belirliyor. Yerel özerkliği üzerine kurulu esnek hiyerarşi sistemi karar verme ve eyleme geçme süreçlerini hızlandırıyor. Halkevlerinin sahayla ilişkilenme biçimi karşılıklı güveni de tesis etmekte. Saha çalışması yapıyorlar, yereli tanıyorlar. Yoldan gelip geçenlerle selamlaşıyorlar, o günkü programlarını hatırlatıp davet ediyorlar. Seher'e mahallenin güvenini nasıl kazandıklarını sorduğumda aşağıdaki cevabı aldım:

Herkesi davet ediyoruz, Türbanlı teyzeler çocuklarını bize emanet ediyor. Çünkü neler yaptığımızı görüyorlar. Bir gelen bir daha gelmek istiyor, komşusuna anlatıyor. Çünkü işlerine yarıyor. Evet bura solcu ama biz Kartaltepe, Çağlayan'a da gidiyoruz. Mutlu Mahallesi gerici hep MHP orası. Sadece soldan beslenmiyoruz. Zaten ben kadınlarla çalıştığım için... Solcuyum da desen kadın eziliyor. Korkuları var, gelmeye çekiniyorlar önce. Buraya çocuklarını bedava kurs var diye getiriyorlar. Sonra mahalleyi dönüştürdüğümüzü görüyorlar. Biz mahalleye sahip çıkınca onlar da bize sahip çıkıyor.

Halkevleri sorumlularıyla yaptığımız toplantılarda, sağlıkla ilgili eğitimlerin Tuzluçayır'da başlamasının uygun olacağını, çünkü bu bölgede talep ve katılımın

3 Seher ile Ankara Barosu'nda düzenlenen 1. Çocuk Çalıştayı'nın ardından kısa bir mülakat gerçekleştirdim. Seher 27 yaşında, üniversite mezunu, özel bir şirkette çalışıyor, bekar ve ailesiyle Tuzluçayır Bölgesinde ikamet ediyor. İşten ardakalan zamanlarında halkevleri gönüllüsü olarak çeşitli faaliyetlerde bulunuyor. 
nispeten fazla olduğu bilgisini almıştık. Tuzluçayır'ın muhalif ve mücadeleci yapısını hatırladığımızda, sistemin üstünden aşarak, alternatif yollardan sağlık hizmetlerine ulaşma arayışı için talebin en çok bu bölgeden gelmesi anlaşılır olmaktadır. Tuzluçayır Halkevlerinde başlayan sağlık eğitimleri, buradaki halkın ücretsiz sağlık hizmeti alma haklarını elde etmek için ürettikleri taktiklerden ${ }^{4}$ biri olarak düşünülebilir. Her bir eğitimde ortalama 10-15 kişi yer almıştır. Katılımcılar, iki veya üç çocuklu ve düşük gelirlidir. Katılımcıların hepsinin çocukları halkevlerinin yaz ve kış okullarına devam etmekte, orada düzenlenen sosyal aktivitelere katılmaktadır. Anne ve babaların çoğunluğu halkevleriyle çocukları sayesinde tanıştıkları bilgisini vermiştir. Bu noktada, buradaki kadın ve erkekler için ebeveyn kimliklerinin önemli olduğu sonucu çıkarılabilir. Buradaki ailelerin geleneksel öğretilerin dışında modern yöntemlerle çocuk yetiştirmeyle ilgili bir arayışlarının olduğu ve bu sebeple sağlık eğitimleri seminerlerinde önceliği çocuk ve ergen gelişimine ve ebeveyn-çocuk ilişkilerine vermiş olduklarını düşünebilir.

\section{Tuzluçayır'da Halkevinin Hikayesi ve Katılımcıların Eylemci Profili}

Akşam altı sularında başlayacak eğitime çevreyi görmek ve ortamdakilerle tanışmak için bir buçuk saat erken gittim. Tuzluçayır'a ulaşıp Halkevini ararken, genelde apartmanların üst katlarındaki tabelalara bakıyordum çünkü bir apartman dairesinde, derme çatma döşenmiş, ofis görünümlü bir mekâna gideceğimi umuyordum. Fakat tam önünde durduğum parkın içindeymiş halkevi. Parka adım attığım andan itibaren şaşırmaya başladım ve birtakım önyargılarla oraya geldiğimi fark ettim. Şehrin çeperinde konumlanan ve sol ideolojiyle ilişkilenen bir mekânın renksiz ve kuru bir ciddiyet taşıyacağına dair bir beklentiden bahsediyorum. Ama işlek bir caddenin yirmi metre yukarısında Ethem Sarısülük Halkevi ve Ali İsmail Korkmaz Parkı afişler, pankartlar ve resimlerle "olağanüstü hal rejimine" rağmen orada durmaktaydı. İsminden cismine, sol idealleri gözler önüne seren "Bu parkın adına karışan yok mu?"

\footnotetext{
4 De Certeau referanslı bir tanımlama olan "taktik", gündelik hayat pratikleri içinde hakim söyleme, iktidarın düzenleme ve disiplinine karşı koyma sürecini tarif eder. Bu pratikler genellikle iktidarın kendi düzenini sağlayan "stratejilerine" karşın, o düzenin içindeki boşlukları keşfedip içeriye sızma eylemleri şeklinde kendini gösterir. Bu bağlamda stratejiler güç ilişkilerinin kullanılmasıyla ilişkiliyken, taktikler gücün yokluğunda gelişen hesaplanmamış, tahmini olan eylemlerle ilişkilidir. Stratejilerin düzen, kural, belirlilik gibi atıfları varken, taktiğin belirli bir yörüngesi yoktur. Taktik, zayıf ve zor durumda olanın kent yaşamı içinde uyguladığı bir tür doğaçlama sanattır diyebiliriz (De Certeau, 2009).
} 
diye sorduğumda bir mücadele hikayesi dinledim. Bina 1970'lerin ortalarında mahalle halkı tarafından imeceyle yapılıyor. Sevgi'nin sözleriyle parkın yapılış hikayesi şöyle:

Herkes bir tuğla koyuyor, harcını karıyor. Bazen mahallenin yaşlıları geliyor diyor ki, "Kızım buranın sıvasını ben yaptım", öbürü diyor "Ben çatıyı aktardım". 12 Eylül Faşist Darbesinden sonra belediye el koymuş binamıza. Burası uzun yıllar belediye işçilerin üstünü başını değiştirdiği, malzemelerini koyduğu bir virane oldu. İzbelikti, hep çer çöp... Gezi Direnişinde Ethem Yoldaşın kaybından sonra geri almaya karar verilmiş. Bir gecede karar veriliyor, oraya gidiliyor, belediyenin işçilerine "Burası halkın evidir, çıkın gidin!" deniyor. İşçileri kovuyor halk, işçiler de hiç itiraz etmeden gidiyor. Sonra hemen kampanya başlıyor. "Bir kitap da sen al getir" diye. Mahalle temizlik yapıyor, badana, boya, eşyalar geliyor. Herkes evinden birşeyler getirdi koydu. Büyük bir şenlikle açtık. Yine arada sıkıntılar, el koyma çalışmaları oldu. Bir keresinde kağıt geldi belediyeden, direnmeyin burası yıkılacak diye. Halk o zaman akın etti. Bir ay nöbet tuttuk, akşamları sazlar çalındı, yenildi, içildi. Oturduk bekledik bütün mahalle, çıkmadık, direndik.

Tuzluçayır Halkevi mahallenin gençlerinin buluşma ve dertleşme mekânı olarak da kullanılmakta. Yaş aralığı 17-25 arası değişen gençler akşam üstleri orada buluşuyorlar. Bazıları lise ve üniversite öğrencisi olan gençlerin bazıları ise seyyar satıcılık (kokoreç, kestane satmak gibi) yapıyor. Bazı gidişlerimde kendi deyimleriyle "ekmek tekneleri" olan kokoreç tezgâhını gündüzleri mekânda koruduklarını görüyorum. Gençler kendi aralarında yaptıkları konuşmalarda birbirlerine eylem, direniş, polisle çatışma, polisten kaçma anılarını anlatmaktalar ve bu sohbetler çoğu zaman kim toplumsal olaylarda daha cesur, kim biber gazına daha dayanıklı, kim polisten en çok dayak yedi konuları üzerinden ilerleyen bir rekabete ve gövde gösterisine dönüşmekte. Eylemlerde ön saflarda olmak, nümayişe katılmak ve kolluk kuvvetleriyle çatışmaya girmek bir meziyet buradaki gruplar için.

Gündelik hayatta kullanılan dil bize o toplumun siyasi, dini, ekonomik ve tıbbi konfigürasyonlarının nasıl düzenlendiğini anlatır. Dilin dolaşımı toplumsal süreçleri ortaya çıkarabilecek kapasitedir (Certeau, 2009: 67-83). Gençler kendilerini "Halkevci" olarak tanımlıyor. Bu tanımlamanın aynısını farklı defalar, farklı kişilerden duydum. Mesela anneler çocuklarının kendilerine sık sık karşı geliyor oluşu için "Ne de olsa halkevci çocuklar bizimkiler, dilleri pabuç gibi" dediğini ya da kendi deneyimlerinden bahsederlerken "halkevci kadınım ben güçlüyüm", "halkevci olmadan önce" gibi ifadeler kullanmaları; kadınların mekânla geliştirdikleri güçlü bağı göstermektedir. Bu 
durumda halkevci olmanın, farklı ve marjinal bir aidiyet biçimiyle kimliklenmek anlamına geldiği düşünülebilir.

Daha önce de pekçok kez halk sağlığıyla ilgili eğitimlerde bulunmuştum. Ama ilk defa, katılımcıların toplumsal bir eylemden çıkıp bir eğitim grubuna geldiğine şahit oluyordum. Erken geldiğim eğitimlerin birinde gençlerle otururken, bir anda içeriye 810 kişilik bir kadın ekibi girdi. O gün "Kadına Şiddete Hayır" eylemi için Kurtuluş'dan Kızılay'a yürümeye çalışmışlar ve polis tarafından engellenip, darp edilmişlerdi. Bu benim için de bir kırılma anıydı. Tam da oradaki gençlerle kaynaştığımı düşündüğüm bir anda sahaya ne kadar yabancı olduğumu fark ettim. Mahalledekilerin gündelik etkinliklerini taklit etmek sizi onlardan biri yapmaya yetmiyordu. Bir toplumsal eylemde darp edilip, ardından anne-baba eğitimine katılma deneyimine tanık olmak beni sahaya dışarıdan gelen bir gözlemci konumuna indirgedi. Aralarındaki konuşmalardan bazı arkadaşlarının gözaltına alındığını anladım. Hepsi çok soğukkanlıydı. Benim kaygıyla "Ne olacak?, "Eğitimi iptal edelim isterseniz?" önerime karşılık, "Bişi olmaz, akşam altıda salarlar" cevabını aldım. Gelen kadın grubu oradaki gençlere, mahalleden bir kadının polis tarafından darp edilmesini anlattı ve konuşmalar yine polisin "acımasızlığı" ve kendilerinin direniş gücü üzerinden devam etti. Bazen kendileriyle dalga geçerek, bazen travmatik olabilecek bir olayı hafifseyerek birbirlerine eylem anılarını anlatmaya devam ettiler. Gözaltılar, eylemler oradaki mikroyapıda günlük hayatın bir parçası olarak algılanmaktaydı.

\section{Tulzuçayır'da Ergen Çocuklar Üzerine Eğitim ve Ebeveynlerin}

\section{Kaygıları}

Psikoloji alanındaki "gelişim" kavramıyla birlikte, insan hayatınının dönemleri evrelendirilmiş, hatta her dönem bir krizle tanımlanmıştır (Gilligan, 1982). Ergenliği insan hayatında vahim bir dönem ve ergenleri de aşırı ihtimam gösterilmesi ve her an gözlenmesi gereken hassas varlıklar olarak kabul eden bir söylemden bahsedebiliriz. Bu çalışma kapsamında yapılan ergenlik dönemine ilişkin eğitimde, tüm bu risk algısı, krizler, korkular ve güven aşınması katılımcı ailelerde izlenmiştir. Sağlıkla ilgili bu söylem patlaması ailelerin de çocukları için endişelerini artırır (Hatun, 2015). Bu endişeyle birlikte sağlık tüketimi, ergenlik ve gelişimsel süreçlerle ilgili alanlara giderek yayılmaktadır (Hatun, 2015). Örneğin, ergenlik belirtileri ilk başladığı anda aileler 
çocuklarının boy uzamasının duracağı endişesiyle endokrinoloji uzmanına başvurmakta ve ergenlik durdurucu ilaçlar daha sık kullanılmaktadır (Condrad, 2008). Bilimsel literatürde ve uzmanların dilinde çatışmalar, çözümlenmesi gereken karmaşalar, erişilmesi gereken hormon düzeyleri gibi kavramlarla ele alınan ergenliğin gündelik hayatın içinde de bir kriz dönemi olarak yer alması beklendik bir durumdur.

Eğitimlerde, bu dönemin "tıbbi olmayan", yaşamın doğal bir süreci olduğu bilgisi vurgulandı. "Kriz" gibi yerleşmiş tanımlamalar, doğal bir süreci tıbbileştirme yönünde etkide bulunmaktadır. Tıbbileştirmenin sorunu ise ortada gerçekten bir hastalık olmaması, bunun sadece bir kabul olmasıdır (Sezgin, 2011). Örneğin Aliye Hanım 10 yaşındaki kızının göğüslerinin tomurcuklanmasını ve kıllanmanın başlamasını "erken ergenlik" diye yorumlamıştı. Aliye Hanım, kızının adet görmesini geciktirmek için hormon tedavileri araştırmaktaydı. Özel hastanelerin tanıtıcı broşürlerinde ya da medyadaki programlarda, "göğüs büyümesi eşittir adet kanaması" ve "o da eşittir boy uzamasının durması" şeklinde kurulan basit denklemin yansıması olarak düşünülebilecek bu endişeye karşın, normal ve ortalamanın farklı kavramlar olduğu bilgisini paylaşmak Aliye Hanım'ın fikrini değiştirdi. ${ }^{6}$

Ergenlerin, uçurumların kenarında savrularak gezen dengesiz varlıklar olarak kurgulanması, ailelere büyük bir kontrol motivasyonu getirmekteydi. Tüm gözlem ve kontrole rağmen karşılaşılan sorunlarda özellikle annelerin kendi yetersizliklerine odaklandıklarını gördüm. Fatma Hanım ${ }^{7}$, oğlunun sigaraya başlamasından kendini sorumlu tutuyordu. "Sahip çıkamadım, işe gittim, başında dursaydım başlamazdı." ifadesi, ailenin sosyal kontrol mekanizması olma görevinin içselleştirildiğinin de göstergesidir. Deniz Sezgin'in de dediği gibi sağlığın bireyselleşmesi insanlarda karşılaştıkları her sorunun kendi yetersizliklerinden kaynaklandığına dair bir algı oluşturmaktadır (2011: 79-82). Kişinin hastalanmasını onun hatası olarak gösteren bu

\footnotetext{
5 Aliye Hanım (35 yaş), sürdürdüğümüz halk sağlığı eğitimlerinin düzenli bir katılımcısıdır. Özel bir kurumda vardiyalı olarak çalışan eși de bazı eğitimlere katılmıştır. İki çocuğu, Tuzluçayır Halkevinin yaz ve kış okullarına devam eder. Aliye Hanım, kurumun organize ettiği çoğu sosyal faaliyetlere (tiyatro, piknik vb) katıldığını belirtmiştir. Tam zamanlı bir işte çalışmayan Aliye Hanım, ev geçimine yardımcı olmak için bazı dönemlerde dantel ve iğne oyası yapmaktadır.

6 Türkiye'de kızlarda ergenlik bașlama yaşları 8-13 ama ortalamanın 10,5 olduğu bilgisi ya da göğüs tomurcuklanmasının büyümenin erken belirtisi olduğu ama hemen ardından adet kanamasının başlayacağı anlamına gelmediği yönünde bilgi (Demirel ve ark., 2005: 39-43) verdikten sonra Aliye Hanım'ın hastaneye gitmekle ilgili fikri değişmişti.

7 Fatma Hanım 38 yaşında, ilkokul mezunu ve evlidir. Üç çocuğu vardır. Görüşme yaptığımızda eşi halen cezaevindeydi (25 Aralık, 2016).
} 
söylem, politik ve ekonomik pratiklerle ilişkilidir. İnsanlarda çocuklarının ve kendilerinin sağlıklarını yeterince koruyamadıklarıyla ilgili suçluluğu ve kaygıyı artırmak, sağlıkla ilgili yapılacak harcamaları da artıracaktır.

Eğitimler sırasında en çok sınır koyma, çatışmaları yönetme, bilgisayar bağımlılığı, beslenme ve abur cubur alışkanlığı, fiziksel gelişim, aşırı tüketimcilik gibi alanlarda sorular geldi. Çocukların ödevleri, temizlikleri ve beslenmeleriyle ilgili konuların sorumluluğu genelde annelerin üzerindeydi. Düzenleyen ve sınır koyan anne olduğu için, en çok anneler ile çocuklar arasında çatışma yaşanıyordu. Anneler yatma saati, sabah okula yetişme, kahvaltı yapmadan kimseyi evden göndermeme, sağlıklı yemekler yapma, ödevleri bitirme, ailecek etkinlik yapma ve burada daha sayamadığım onlarca görevin sorumluluğunu üstüne almış görünüyordu. Babalar ise gerekli yerde müdahale eden, çocuklarla fazla yüz göz olmayan figürler olarak kendilerini ön plana çıkardılar. Sosyalist söylem, kadın erkek eşitliği ya da eviçi emeğin paylaşııması söz konusu olduğunda ataerkil bariyere takılmış görünmekteydi. Annelerin eşit olmayan görev paylaşımı konusunda farkındalığı vardı, bazıları şikâyet de ediyordu. Bazıları ise eşlerinin cumartesi günleri dahil geç saatlere kadar çalıştığını, ev ve çocuklarla ilgilenmeye vakitleri olmadığını söylüyordu.

\section{Biyoiktidar Karşısında Direnişin İmkanları ve Sınırlarına Tuzluçayır'dan Bakmak}

Aşağıda bahsi geçen örnekler, tıbbi söylemi hem içerleyen hem de dışında olan, bitmeden ve sürekli yenilenerek devam eden bir mücadele sürecini anlatmaktadır. Bu sürecin, bazen müzakere edilerek, bazen doğrudan kabul ve tavizlerle bazen de çatışma ve direnişle devam ettiği söylenebilir. Tıbbi söylem ile, insan varlığının genel olarak tıbbileştirilmesi kastedilmektedir. Yukarıda da ayrıntılı bir şekilde bahsedildiği gibi, tıp bir yandan iktidarını normlar belirlemek suretiyle kurmakta, diğer yandan icat edilen normlar iktidarın özneleşme biçimlerinin işleyebileceği atmosferi sağlamaktadır (Foucault, 2007: 78). Michel Foucault'nun biyopolitika dediği şey de tam bu söylem alanına ve buradaki yönetimselliğe tekabül eder. İlk örnek tıbbi söyleme karşı hakikat arayışının sorgulandığı, söylemin çelişkilerinin belirdiği farkındalıklar ile ilgilidir. İkincisi, Cami-Cemevi Projesinin hastaneye çevrilmesiyle sonuçlanan bir direniş pratiğinin öyküsüdür. Üçüncüsü ise, sistem içinde çözüm üretilemediği için ötelenen ve yok 
sayılan Fatma Hanım ile çocuklarının sürekli taviz vermek zorunda kaldıkları hayatlarından bir kesitin hikayesidir.

\section{Iktidar Stratejilerine Karşı Bir Taktik Örneği}

Tuzluçayır mekân olarak kentin sınırında, söylem de en çok bu sınırlarda kırılmakta. Ulus-devletlerin makbul vatandaş projesinin katı yaptırım gücüne karşı oluşan direniş potansiyelleri en çok sınırlar dediğimiz, normlardan uzaklaşan mekânlarda ve insanlarda ortaya çıkmakta. Güçlülere karşı zayıfın savaşı adı konulmamış taktiklerle gündelik hayatın içinden yıkılmakta (Certeau, 2009: 114). Taktikleri, yerel kültürün deneyimleriyle, kolektif belleğin birikimiyle bugüne taşınmış gündelik hayat performansları olarak düşünebiliriz. Katılımcılarla çocuk yetiştirmedeki tutarlılık üzerine konuşurken, bir anne şunları söyledi: "14 yaşındaki oğluma bir türlü sabah erken kalkma ve okula yetişme sorumluluğu veremiyorum. Her sabah onu erken kaldırmak için uğraşıyorum.” Bunun üzerine ben, bir takım önerilerde bulunurken, çocuğun babası söze karıştı:

Hocam ben istemiyorum ki çocuk her gün sustalı maymun gibi okula yetişsin. Geç git oğlum diyorum, sistemi protesto et. Ne olacak okula yetişecek de... Benim gibi eninde sonunda vardiyalı çalışacak. Yarım saat geç gitse ne kaçıracak, ne öğretiyorlar sanki? Sistemin ezmesi için adam yetiştiriyorlar. Bir de ben evde ezemem oğlumu. Geç git oğlum diyorum, ben imzalarım geç kağıdını! Ezdirme kendini devlete.

Ben bu noktada sağlık tertibatının bir temsilcisi olarak, uzmanlıktan aldığım iktidarla rıza kazandırıcı bir konumda olduğumu hissettim. Tüm bilgi repertuarım ve hakikat anlayışım sistemin stratejilerini benimsetmek üzerine kuruluydu. İçten içe katılımcı babanın söylediklerine hak versem de, uzman kimliğimle "istediğiniz saatte çocuğunuz okula gitsin" diyememenin çelişkisini yaşadım. Daha sonra yapılan eğitimlerdeki geribildirimlerden ve gözlemlerimden bu çelişkiyi oradaki ailelerin de yaşadığını fark ettim. Ailelerin çocuklarıyla ilişkileri iki yönlü ve çatışmalı bir gerilim üzerinden ilerlemekte. Sisteme uyumlu çocuk yetiştirmek ile muhalif ve politik idealler arasında bir çiftdeğerlilik vardı.

Ergenlikle ilgili süreçleri içine alan tıbbileştirme söyleminden aileler de etkilenmişti. Yukarıda da belirttiğim gibi, bugünlerde popüler olan erken ergenlik, boy 
uzaması, hormon tedavileri konusunda endişeleri olanlar vardı. ${ }^{8}$ Bir diğer medikalize edilen konu ergenliğin "kriz" olarak felaketleştirilmesiydi. Ergenliğin doğal bir süreç olduğu, bu dönemde yaşanan çatışmaların ve başkaldırının başarısızlık değil başarı olduğunu anlattıktan sonra onların ergenlik anılarını konuşarak devam ettik. Kendi deneyimlerini hatırlamak, çocuklarıyla empati kurmalarını kolaylaştırdı. Her şeyden önce çocuklarıyla yaşadıkları çatışmaların bir patoloji olmadığını duymak onları rahatlattı. Katılan tüm anneler teker teker kendi yetersizlikleriyle ilgili endişelendiklerini, kendilerini yetersiz bulduklarını söylediler. Bu yetersizlik duygusunun tıbbi söylemin giderek bireyselleşmesi ve sağlıklı olma sorumluluğunu bireyin üstüne atmasıyla ilgili olduğu düşünülebilir. Devlet çocukların sağlığından aileyi sorumlu tutmakta, aile içinde bu yük, iktidar hiyerarşisi içinde en alt kademede olan kadına kalmaktadır. Örneğin, başka bir anne iki yıldır üniversite sınavını kazanamayan oğlu için kendini suçlamaktaydı. Oğlunu yeterince çalıştıramadığını, kötü alışkanlıklar edinmesini önleyemediğini düşünmekteydi. Bu kadar muhalif bir grubun, söz konusu annelik rolleri olduğunda bu kadar muhafazakâr olması dikkat çekiciydi. Gönül rahatığıyla "sistemi protesto et" diyen bir babaya karşın bir anne, eğitim sisteminin yetersizliğini gözardı ederek oğluyla ilgili tüm başarısızlığı kendi üzerine alıyordu.

\section{Bir direniş hikayesi: Cami-Cemevi Nasıl Hastane Oldu?}

Mahalle sakinlerinin sağlık ihtiyaçlarını nasıl giderdiklerini, sağlık uzmanlarıyla ilişkilenme biçimlerini araştırırken, bölgede yapılması planlanan "Cami-Cemevi" projesinin zorlu bir mücadele sonucunda kamu hastanesine çevrildiğini öğrendim. Nüfusunun büyük çoğunluğu Alevi olan Tuzluçayır, Sünni Müslüman kodlarını hızla neoliberal politikalara eklemleyen muhafazakâr iktidar için dikenli ve ayrıksı bir bölgedir. Cami-Cemevi Projesi, tüm mekanizmaları yaşamı belirlemek için seferber olan iktidarın biyopolitiği olarak düşünülebilir. Hayatı geliştirmek adına, kimliklerin sınırlarını yeniden çizmeye çalışan, düzenleştirici yaşam teknolojisinin bir yansıması olan proje, mahalle halkı tarafından da bir asimilasyon teşebbüsü olarak algılanmıştır. Sevgi'nin sözleriyle bu hikayeyi aktarıyorum:

\footnotetext{
8 Çoğunun bir tanıdığı ergenlik durdurma tedavisi almaktaydı ya da kemik yaşı ölçümüne gitmişti ya da medyadan bu konu hakkında bir şeyler duymuştu.
} 
Alevi Kurumlarıyla irtibat halinde, halkla beraber bir dayanışma örgütledik. Büyük mücadele verdik. Bu uğurda Ahmet Atakan yoldaşımızı kaybettik. Buranın temelinde kan var. Kahvelerdeki amcalardan, evinde örgü ören teyzelere kadar tek tek dolaştık kimse istemiyor Cami Cemevini. Dedelerimize, büyüklerimize sorduk: "Böyle ibadet mi olur?", diyor. İmza topladık bütün mahalleden. Aldırmadılar, 7-8 Eylül 2014'de gelip açıış yaptılar. Bunun üzerine mahalle ayaklandı. $O$ zaman çatışmalar başladı. Her akşam devam etti. Mahalleyi polis bastı, hatta böyle kalekol gibi bir alan oluşturdu polis kendine. Yılmadık. Bu süreç Tuzluçayır halkını çok yıprattı ama direndik. Esnaf iş yapamadı, gaz fişeği ile gözü çıkan, yaralanan yoldaşlarımız oldu. Direniş süresince halk ve esnaf hep yanımızdaydı. Çıkın bakın sokaklara herkesin saksısı camının önündedir. O günden kalma bir alışkanlık. Çünkü o dönem, polise yardım etmek için faşist ve dinci gruplar da bastı mahalleyi. Başka yerlerden geldiler. Bunlar mahalleye girince, halk saksıları atıyor üzerlerine. Direniş sürerken dava da açtık yapımın durdurulması için, davayı kazandık. Yapım durduruldu. Davayı kazanınca "Biz bu alanı ne yapalım?" diye düşündük. Gene mahalleye sormaya karar verdik. Büyük bir çalışma yaptık, ekipler oluşturduk. Gecemizi gündüzümüze kattık. Çağlayan, Kartaltepe ve Tuzluçayır'da kapı kapı dolaştık. Tam 800 binaya girdik, 5000'e yakın insana sorduk, burada ne yapalım diye, Cami'mi, Cemevi'mi yoksa hastane mi? Yüzde doksanı Alevi olan mahallede üç beş kişi "Cemevi olsun" dedi biliyor musunuz? Herkes hastane istedi. Gerekçeleri de şöyleydi: "Temelinde kardeşimizin kanı olan bir yerde biz ibadet edemeyiz". Sonra bir imza kampanyası daha başladı. Bu imzalarla Mamak belediye meclis üyelerine gittik hastane istiyoruz diye. Mamak Belediye Başkanı AKP'li ama meclis üyeleri ve imzalarla gidince ikna oldu. Şimdi burada hastane inşaatı başlayacak.

Bu bölgede en yakın kamu hastanesi Ulus'daki Ankara Hastanesi. Bölge sakinleri ulaşım zor olsa da sağlık hizmetlerini oradan alıyor. Bölgede ekonomik durumu daha iyi olanların faydalandığı bir tane de özel hastane mevcut. Görüşmecilerden alınan bilgilere göre, sağlıkta dönüşüm projesiyle kamu hastanelerinin hizmet kalitesinin düşmesi, hekime ulaşımın zorlaşması ve randevuların yığılması bölge halkının yerel bir hastane istemesinin temel sebebi olmuştur. Müzakerelerden kanlı çatışmalara kadar direnişin birçok boyutunun yer aldığı bu süreç, neoliberal işleyişin toplumsal tepkilere varsayıldığı kadar dirençli olmadığının da kanıııır (Hardt ve Negri, 2015: 77). Siyasal temsil, kamuoyu teşkil etmek, baskı mekanizmaları oluşturmak "başka dünyaları" mümkün kılabilir. Cami-Cemevi'nin hastaneye dönüş süreci, yeni kamusal alanlar ve yeni cemaat biçimleri oluşturma gücüne sahip olan kurucu mücadelelere bir örnek olarak düşünülebilir. 
İktidar ilişkileri güç ilişkileridir ve her zaman tersine dönebilen çatışmalardır. Her zaman galip gelen bir iktidardan bahsedemeyiz. Bir başka deyişle iktidarın tahakkümünün kesintiye uğratılıp zayıflatılması mümkündür. (Foucault, 2007: 176). İktidar ile özgürlük birbiriyle çelişkili, birarada olmayan kavramlar olarak görünse bile aralarında karmaşık bir bağ vardır. İktidar, özneler özgür olabildiği zaman uygulanabilir, bir başka deyişle iktidar varlı̆ı̆ıı gösterebilmek için özgürlüğünü talep edecek özneleri ister. İktidar ve özneler süregiden bir çekişme halindedir (Scott, 2018). Direnişi de tıpkı iktidar gibi düşünmek gerekir. İktidarı ve ona karşı direnişi sonsuz bir hareket döngüsü içinde, köken veya kaynak aramadan kavramak yerinde olur (Scott 1985: 38). Bu şekilde baktığımızda direnişin yekpare, merkezden gelen bir etki değil parçalı, noktasal ve yerel olduğunu görebiliriz. Bu noktada Foucault'nun çok bilinen, "iktidarın olduğu yerde direnme vardır, ancak ya da doğrusu bu yüzden direnme hiçbir zaman iktidara göre dışsal bir konumda değildir" (2007: 73) sözleri açıklık kazanır. Camii-Cemevi örneğinde olduğu gibi direnme noktaları iktidar şebekesinin her yanında varlık gösterebilmektedir. Dolayısıyla iktidara karşı topyekûn bir reddiyeden, tek bir direnme mekânından, direnişin değişmez bir yasasından bahsedemeyiz. Direnişler ya da mikro-direnişler yoluyla değişim mümkün olmaktadır.

\section{"Çıplak Hayatlar": Fatma Hanımın Çocukları Ne Olacak?}

Eğitimlere katılan ve görüşmeyi kendisi talep eden Fatma Hanım'ın eşi hapistedir. Çocukları Haydar (14), Hasan (10) ve Esin (8) ile birlikte yaşamaktadır. Hasan'ın hastalığına kadar olan süreçte, sigortalı bir işte çalışıp evin geçimini sağlamaktadır Fatma Hanım. Fakat mesai saatleri uzundur, işe gittiği zamanlarda çocuklarını bırakacak kimse yoktur. Hasan birinci sınıfta okuma yazmayı öğrenemez. Okuldan çağııılar, "özürlü raporu" almasını, o zaman okula devam edebileceğini söylerler. Hasan'a zihinsel engelli raporu verilir, ayrıca "davranış bozukluğu" olduğu söylenmiştir. Fatma Hanım, görüşmemiz boyunca "davranış bozukluğunun" babasından geçtiğini vurguladı. Hasan ikinci sınıfta okulla birlikte özel eğitim ve rehabilitasyon kurumuna devam eder. Dördüncü sınıfta konu komşudan Hasan'ın okuldan kaçtığını duymaktadır, Hasan'ı okula devam etmesi için tembihler, nasihat eder, kızar, döver. Tam da o günlerde okuldan haber gelir, Hasan devamsızlık sınırını geçmiştir. Hasan'ın her gün okuldan kaçtığını ve Satılmış adındaki bir adam tarafından sigaraya 
alıştırıldığını öğrenir Fatma Hanım. Hasan günde üç paket sigara içmekte, evden para çalmakta ve okula gitmeyi reddetmektedir. Fatma Hanım, aynı "davranış bozukluğunun" Haydar'da da olduğunu belirtti. Haydar da okuldan kaçıp sigara içmektedir. Hasan'ı 15 Kasım 2016'da Yenimahalle Devlet Hastanesi Çocuk ve Ergen Psikiyatrisine yatırırlar. Görüşmenin gerçekleştiği sırada Hasan hâlâ tedavi sürecindedir. Haftaiçi hastanede kaldıkları, haftasonu evci çıktıkları bir düzen başlamıştır. Fatma Hanım hastanede Hasan'ın yanında kaldığı için işi bırakmak zorunda kalır. Geçimini borçla ve konu komşu yardımıyla sağlamaktadır. Diğer çocukları ne yaptığını sorduğumda "Bazen babaanneleri geldi, bazen tek kaldılar" yanıtını aldım. Hasan'a konulan tanı "dikkat eksikliği hiperaktivite bozukluğu"dur (DEHB). ${ }^{9}$ DEHB tanısı, eğitim, sağlık, sigorta sisteminin ve çalışan kadınların çocuklarının bakım sorununun üzerini örtmüştü. Fatma Hanım, Hasan'ın, DEHB olduğu için bu durumda olduğuna inanmaktadır. Tedavi sürecinin nasıl gittiğini sorduğumda Fatma Hanım şöyle yanıtladı:

Çok küfür ediyor, günde üç paket sigara... Hastanede bıraktırdılar ama geçen eve geldim bir baktım babaannesiyle oturmuş karşılıklı sigara tüttürüyorlar. [Babaanne 66 yaşında] Ne yapsın o da laf söz dinletemiyor bari evden çıkmasın benle içsin demiş. Gene evden kaçıyor, kafasına göre dağ bayır geziyor. Satılmış diye biri sigara vermiş hep. El uzunluğu da var bunda. Geçen $A 101$ 'de yakalanmış. Tutanak tuttular, tanıdıklar varmış, beni çağırdılar yırttık attık tutanağı... Bu sene üç gün okula gitti. Gönderemiyorum.

Fatma Hanım'ın benimle görüşmek istemesinin sebebi Hasan'ı okula gönderebilmek için çare aramasıydı. "Nasıl gidecek bu okula?" derken, kapının arkasından bizi dinlediğini anladığım Hasan "Gitmeyecem okula" diyerek içeri daldı. Fatma Hanım, "O

\footnotetext{
9 Okul çağı çocuklarında \%3-5 oranında görülen DEHB'nun tanısı esas olarak anamneze dayanılarak ve tanı kriteleri temel alınarak konur. Bir başka deyişle bu tanının herhangi bir fizik muayene bulgusu ya da laboratuvar testi bulunmamaktadır. DEHB tanısı alan çocuklar genellikle okulda umulanın altında performans gösterirler. Dikkatle ilgili sorunları derslerde öğrenmelerini güçleştirir, ödevlerinin başına oturmakta ve ödevlerini tamamlamakta zorlanırlar. Sabırsız ve sırasını beklemekte zorlanan çocuklardır. Dürtüsel oldukları, düşünmeden hareket ettikleri ve kurallara uymakta zorluk yaşadıkları için sıklıkla arkadaşlarıyla sorun yaşarlar. Verilen görevleri sıklıkla unutur, başladıkları işleri tamamlamakta zorlanırlar. Unutkan oldukları ve sıklıkla eşyalarını kaybettikleri için aileleri ve öğretmenleri onları "sorumsuz" olarak niteleyebilir. Sıklıkla ufak tekef kazalar atlattıklarından "sakar" oldukları da söylenir. Tüm bunlar çocuğun günlük yaşamını, sosyal ilişkilerini ve okul başarısını olumsuz etkiler. Bir çok psikiyatrik hastalıkta olduğu gibi DEHB'de de etiyoloji kesin olarak belirlenememiştir (Öner vd., 2003: 97-99).
} 
zaman yurda gidersin, alırlar seni" diye bağırdı. Hasan'ı okula göndermeyi başaramadığı için Fatma Hanım'ı devlet gözlem altına almış.

Sosyal hizmet uzmanları gelecek... Yurda almazlarsa, beni beğenirlerse inşallah maaş bağlayacaklar. Bütün umudum bu... O zaman sahip çıkarım Hasan'a da Haydar'a da. Konu komşu yardımıyla yaşıyoruz, borç içindeyiz. Bu okula bir gitse, maaş da bağlayacak devlet bana. Çaba gösteriyorum, didiniyorum ama bunlar beyinlerinde bitirmiş. Bunların istediği hayat serseri hayatı. Hayat bana hep zorluk hep zorluk.

Hasan'ın nasıl okula gönderilebileceğiyle ilgili sorunun cevabı psikiyatri ve psikoloji disiplinin sınırları içinde değildir. Çünkü asıl mesele "Hasan'ın okul problemi" ya da psikiyatrik tanısından ziyade, sosyal güvenlik sistemi içindeki çıkmaz durumdur. Bu noktada biyopolitikanın somut izlerini de sürebiliriz. Çünkü, sisteme uyum sağlayamamanın tıbbileştirildiği ve bu durumun da bizatihi birey tarafından içselleştirilip kendini düzeltmeye çalıştığı bir örnekle karşı karşıyayız. Bir başka deyişle, politik bir sorunun tıbbileştirilmesi ve kişisel-istisna bir duruma indirgenmesini görmekteyiz. "Devlet kendi eğitim kurumuna emanet edilmiş olan bir çocuğu henüz okulda tutmayı beceremezken, hangi hakla ve gerekçeyle Hasan'a el koyabiliyor?" sorusu sürecin analizi için önemli görünmektedir. Çünkü çocuğu okulda tutamamanın tüm sorumluluğunun Fatma Hanım'da görülmesi, sağlıklı kalma yükümlülüğünü kişinin sırtına yükleyen bireyci ekonomi politik yapılanmaların bir ürünüdür. Hasta olduysanız kendi mesuliyetlerinizi yerine getiremediğinizle ilgili imalar hatta bazen açıkça suçlamalara maruz kalmak alışıldık bir durumdur. İktidarın kurumları, çocuklar okula gönderil(e)mediği için, "ihmal” gibi bir gerekçeyle çocukları koruma altına alacaktır. Fakat arka plana baktığımızda, çocuklarına bakım verecek kurum bulamayan, sosyal güvenceden mahrum yalnız bir anne görmekteyiz. Fatma Hanım çalışıp hane geçimini sağladığında çocuklar başıboş kalmakta, çocuklarıyla ilgilendiğinde ise aile gelirden mahrum kalmaktadır. Diğer yandan Fatma Hanım, büyük oranda sosyal haklara erişememekle ilgili olan bu durumu kendi yetersizliği olarak algılamakta, iktidarın kurumlarıyla ilgili bir sorgulamaya girmemektedir.

İktidar dört koldan sigara karşıtı kampanya yürütürken, sigaranın görünürlüğü, satışı, içilecek mekanlar her geçen gün daha çok kısıtlanırken, on yaşındaki Hasan'ın eğitim saatleri içinde nikotin bağımlısı haline gelmesini istisna bir durum olarak 
açıklamak çok kolay olurdu. Foucault, iktidar ve özne meselesiyle ilgili olarak "insanın ne pahasına kendisi olduğu" sorusunu ortaya atar. Bu noktada iktidar kavramı yerine yönetimsellik ve onunla bağlantılı biyopolitika kavramları üzerinden düşünmek gerekir. Hasan'ın ve Fatma Hanım'ın hayatı biyopolitikanın sınırlarında yer alıyor. Korunup kollanacak hayatlar varken, harcanıp gözden çıkarılabilecek hayatlar da vardır. Fatma Hanım ve çocuklarının hayatları gözden çıkarılacak olanlardan... Sistem onları içleyerek dışlıyor. Yoksulluk ve sebepleri görmezden gelinirken, okul, hastane, sosyal güvenlik kurumları ve uzmanlardan oluşan sistemin mazereti Hasan'ın DEHB tanısı ve Fatma Hanım'ın yetersizliği olarak görünmekte. Fatma Hanım'ın öyküsü, "öteki" bile sayılmayacak kadar uzakta, görülmeyen, duyulmayan, yok sayılan, yaşamının bir değeri olmayan homo sacer kavramını hatırlatır. ${ }^{10}$ Homo sacer düzenleme, normalleştirme, sıradanlaştırma, terbiye etme sürecinin dışında bırakılıp "ölmeye terkedilenler"i anlatan bir kavramdır. Giorgio Agamben toplama kampındaki insanların durumuna bu kavramla işaret eder (Akt. Lemke, 2013: 77-84). Fatma Hanım "toplama kampında" değildir, ölmeye de terk edilmemiştir. Günümüz toplumunda ötekilerin, yararsız ve gereksizlerin gönderildiği toplama kampları artık yok ama, küresel dünyada ötekiler her yerde, yanıbaşımızda yer alır. Ölüm politikalarının yerine ise çok daha kurnaz olan, "yaşatmaya çalışmış gibi yapma" anlayışı yerleşmiştir. Kaynaklara ulaşabilenler sağlıklı yaşama da ulaşmaktadır. Ötekilere, en kıyıda kalanların payına ise gözden çıkarılmak düşer. Fatma Hanım ve üç çocuğunun öyküsü, sistemin sorunlarını çözüyor gibi yaptığı gözden çıkarılmış hayatlara aittir. Dışlananın ne hakla ve hangi söylemsel dayanaklarla dışarıda kaldığı sorusunu cevaplamak oldukça güç. Ancak bu cevabın izini sadece içeride değil dışarıda sürmek de gerekli. Tam da bu yüzden dışarıda kalanlara bakmak ve onların zorla duyulan seslerine dikkatimizi vermek dışlama süreçlerinin nasıl işlediği hakkında fikir verecektir. Fatma Hanım'ın hayatındaki bu kesiti anlamak bu yüzden önemli. Foucault'nun dediği gibi, bir kültürün kendisi için dışarısı olacak şeyi reddetmek için kullandığı mekanizmaların tarihine bakmak önemli (Foucault, 2005: 23).

\footnotetext{
10 Homo sacer, "kutsal insan" anlamına gelmektedir. Agamben Homo Sacer isimli kitabında, Antik Yunan siyasetindeki "çıplak hayat" (zoe) ve "politik hayat" (bios) arasındaki ayrımı modern toplumsal yapıların biyopolitika odaklı çözümlemesi için kullanır. Agamben'e göre, modern iktidarın kendini var edebilmesi için "çıplak hayat"ı dışlaması gerekir. Ancak bu dışlama, aynı zamanda bir içlemedir. Çıplak hayat siyasal sistemin içinde yer alır ama bir istisna hali olarak da dışlanır (Agamben, 2013: 15-16).
} 


\section{Sonuç}

Kültürel alan ile iktidarın ilişkisinde tarafların hiçbiri tamamen manipule edilemez. İktidar, toplumu ve kültürü kendi lehine dönüştürecek şekilde aygıtlar üretir. Ama, toplum da edilgen değildir, iktidarın aygıtlarına karşı her zaman yeni direniş pratikleri de üretilir. Yeniden üretim ile direniş, yapı ile özne arasında diyalektik bir ilişki vardır. Iktidarın yeniden üretim çabaları, kendine has direnişler ile karşılaşır. Bu direnişler bazen özgürleştirici olabildiği gibi bazen bizatihi iktidarı besleyen bir forma dönüşebilir. Kültürel alan, "çatışma", "direniş", "müzakere", "hakim ve bağımlı kültürler", "alt kültürler" gibi kavramlarla hegemonik bir zemin kurabilir. Bu zemin, farklı sınıf, etniklik, cinsiyet ya da ideolojilerdeki öznelerin politika yapabildiği, çatışabildiği ve yeni direniş yolları geliştirebildiği bir platforma dönüşebilir. Michael Hardt ve Antonio Negri, yeni direniş figürlerinde, iktidarın hem karşısında hem de içinde olmanın ön plana çıktığını söyler (2015: 47). Iktidar her yerde ise ve bireyi denetleyebiliyor ise, kişilerin öznel deneyimlerinden yola çıkarak o deneyimi kuran söylem hakkında bir fikir sahibi olabiliriz. Özneyi anlamaya başladığımızda iktidarı ve bilgiyi de çözümlemeye başlamış oluruz. Biyopolitika ve onun bir vasıtası olarak işleyen yönetimsellik, bir hakikat yaratarak gündelik hayatı kurabilir ama diğer yandan iktidardan kaçabilen, ona karşı gelebilen direnme alanları da vardır. Özne dediğimiz şey o kadar da pasif ve denetlenebilir değildir ve herbirimizin küçük direniş odakları yaratan mikropolitikalar oluşturabilme kapasitemiz vardır. Bir iktidar tipi olan biyoiktidardan kaçış ve direniş imkanlarını yaratmak üzere yapılan her şey mikropolitika olarak adlandırılabilir. Biyopolitikanın oluşturduğu kuşatmadan sıyrılabilmek kaçış ya da direniş odakları yaratabilen taktiklerin her birini mikropolitikalar olarak ele alabiliriz. Tuzluçayır bölgesi, hem Alevi nüfusun yoğunluğuyla hem de sol kültürü benimsemiş olması nedeniyle, mikrodirenişlerin üretilebildiği bir topluluğun mekanıdır. Bu yönüyle iktidarın her daim denetlemeye çalıştığı, kontrolü sağlayamadığında kriminalize edip, ötekileştirdiği öznelerin bulunduğu bir mücadele alanıdır.

Tuzluçayır Halkevindeki süreç, insan yaşamının iktidar ilişkilerinden azade düşünülemeyeceğine bir örnek olarak düşünülebilir. Fakat aynı zamanda, iktidar ilişkilerine direnebilmek için her zaman yeni yollar bulunabileceğini de gösterir. Gündelik hayatın sıradan anları içinde sosyal teorinin kalbinin attığını görebiliriz. Biyopolitika normatif insan tanımlarıyla nüfusu idare eder, ölçülü ve normlara uygun 
yaşam tıbbi söylemle idealize edilir. Sorun çıkarmayan, tüm varlığıyla ve hatta duygularıyla da işlevsel ve dinamik olmaya çalışan bir insan tahayyülü sağılılı olma söylemiyle senkronize olur. Iktidarın ilkeleri her yerde benzer şekilde işlemekte ve üretilmekte, bu yüzden iktidar artık her yerde. Fakat aynı nedenle de iktidar büyük ölçüde kırılgandır. Tuzluçayır Halkevindeki kolektif ruhu ve orada yapılanları -ücretsiz eğitimler, kurslar, boş zaman etkinlikleri, sağlık hizmetleri- direniş taktikleri olarak yorumladım. Bütün o direnişler, mücadeleler ve politik eylemlerle geçen toplumsal sürecin pratiği, biyopolitik üretim rejimleri içinde boyun eğdirilen ve sömürülen bir figür haline gelmiş olanlara karar alabilme, arzularını yönetebilme olanakları yaratıyor. Söylemin kırılması, kişilerin özgürleşmesi için imkân vaat ediyor. İktidar yapıları ve ilişkileri arasında farklı özneler ve kimlikler kurulabiliyor. Kimliklerin geçirgen ve kırılgan yapısı biyopolitik söylemlerle etkileşime geçebiliyor. Halkevi çevresinde örgütlenen toplumsal yaşamın dokusuna sosyalizm fikri derinlikli bir şekilde nüfuz etmiş olsa bile, neoliberal söylemin bu dokunun içine sızabildiği görülebilir. Ergenlik krizi söyleminde ya da cinsiyetler arası rol paylaşımında olduğu gibi, politik olarak bilinçli olan kimlikler biyopolitik söyleme eklemlenebiliyor. İktidar ile kimlikler arasında, bazen kimliklerin iktidarın söylemini kırdığı bazen söylemin kimlikleri ele geçirdiği, her an müzakere edilen, direnme ve teslim olma arasında gidip gelen bir ilişki var. Biyopolitik söylemin izlerini sürmek amacıyla başlayan saha deneyimim, her yerde olan ve herkesi denetleyebilen iktidara rağmen, düşünen, eyleyen ve direnen öznelerin özgürleşme kapasitesini de gösterdi. Tuzluçayır Halkevi, sistem içinde çözüm arayıp eli boş dönenlerin sorunlarını çözmeye çalışan yerel ve mikro ölçekte kurulan bir oluşum olarak hem bir dayanışma hem de direniş, mücadele hattı olarak değerlendirilebilir. 


\section{Kaynakça}

Agamben, Giorgio (2013). Kutsal Insan: Egemen Iktidar ve Çıplak Hayat. Çev., İsmail Türkmen. İstanbul: Ayrıntı.

Condrad, Peter (2008). The Medicalization of Society: On the Transformation of Human Conditions into Treatable Disorders. JHU Press.

Creswell, John W. (2016). Nitel Araştırma Yöntemleri: Beş Yaklaşıma Göre Nitel Araştırma ve Araştırma Deseni. Ankara: Siyasal Kitabevi.

De Certeau, Michel (2009). Gündelik Hayatın Keşfi, Cilt I. Çev., Lale Aslan Özcan. Ankara: Dost.

Delibaş, Kayhan (2013). "Sağlığa İlişkin Korkular: Güven Erozyonu Bağlamında Sağlık Korkularını Anlamlandırmak." Kapitalizm Sağığa Zararlıdır. Osman Elbek (der.) içinde. Istanbul: Hayy Kitap. 101-113.

Demirel, Fatma, vd. (2005). "Çocuklarda Boy Kısalığında Etiolojik Etmenler." Türk Pediatri Dergisi, 40: 39-43.

Deppe, Hans U. (2011). Sağılı Hizmetlerinin Doğası: Metalaştırılmaya Karşı Dayanışma. Kapitalizmede Sağıı, Sağlıksızlık Semptomları. Çev., Umut Haskan. İstanbul: Yordam.

Elbek, Osman ve Emin Baki Adaş (2009). "Sağlıkta Dönüşüm: Eleştirel Bir Değerlendirme." Türkiye Psikiyatri Derneği Bülteni, 12(1): 33-44.

Emerson, Robert M., Rachel I. Fretz ve Linda L. Shaw (2008). Bütün Yönleriyle Alan Çalışması Etnografik Alan Notları Yazımı. Çev., A. Erkan Koca. Ankara: Birleşik Yayınları.

Ercan, Fuat. (2013). "Meta Neler İçerir? Sağlık Hizmetlerinin Metalaşması." Kapitalizm Sağıı̆a Zararlıdır. Osman Elbek (der.) içinde. İstanbul: Hayy Kitap.10-27.

Ergül, Tamer Y. (2009). "Neoliberalizmin İkilemi: Büyük Devlet ya da Azalan Toplam Karlar." Eskişehir Osmangazi Üniversitesi IiBF Dergisi, 4(2): 18-25.

Foucault, Michel (2002). The Archaeology of Knowledge. Çev., A. M. Sheridan Smith. New York: Routledge.

Foucault, Michel (2007). Iktidarın Gözü. Çev., Işık Ergüden. İstanbul: Ayrıntı. Foucault, Michel (2005). Büyük Kapatılma. Çev., Ferda Keskin. İstanbul: Ayrıntı. Gilligan, Carol (1982). In a Different Voice. Harvard University Press. Halkevleri (6 Şubat 2017). "Halkevleri içinde." http://www.halkevleri.org.tr 
Hamzaoğlu, Onur (2011). "Sağlık Reformu Pandemisi: Sağlığın Ekonomi Politiği." Kapitalizmin Krizi ve Sağlık içinde. Ankara: TTB Yayınları.

Hardt Michael ve Antonio Negri (2015). Imparatorluk. Çev., Abdulah Yılmaz. İstanbul: Ayrıntı.

Hatun, Şükrü (21 Aralık 2016). "Kız Çocuklarında Erken Ergenlik: Endişeler ve Gerçekler." http://www.ntv.com.tr/saglik/evlerde-kanser-yapan-radon-gaziolcumleri-basladi. Erişim tarihi: 17 Şubat 2017.

Illich, Ivan (2014). Sağlığın Gaspı. Çev., Süha Sertabiboğlu, İstanbul: İletişim.

Karaaslan, Halise (2003). "Kamusal Ortam Olarak Halkevleri." Ankara Üniversitesi Sosyal Bilimler Enstitüsü Yüksek Lisans tezi.

Koyuncu, Emre (2016). "Foucault'nun Siyaset Felsefesinde Biyopolitikanın Doğuşu." Biyopolitika 2. Cilt, Foucault'dan Günümüze Biyopolitikanın Izdüşümleri. Onur Kartal (der.) içinde. Ankara: Nota Bene.

Lemke, Thomas (2013). Biyopolitika. Çev., Utku Özmakas. İstanbul: İletişim.

Merriam, Sharan B. (2015). Nitel Araştırma Desen ve Uygulama Için Bir Rehber. Çev., Selahattin Turan. Ankara: Nobel.

Öner, Pınar, Özgür Öner, Ayla Aysev vd. (2003). "Dikkat Eksikliği Hiperaktivite Bozukluğu." Türk Tabibler Birliği Dergisi, 12(3): 97-99.

Patton, Michael Q. (2002). Qualitative Research and Evaluative Methods. London: Sage.

Scott, Joan C. (2018). Tahakküm ve Direniş Sanatları. Çev., Alev Türker. İstanbul: Ayrıntı.

Sezgin, Deniz (2011). Tıbbileştirilen Yaşam Bireyselleştirilen Sağlık: Çelişkiler, Alternatifler ve Sağlık Iletişimi. İstanbul: Ayrıntı.

Sofracıoğlu, Nail (2005). “Başkentin ‘Küçük Moskova’sından Kesitler: 1970'ler ve 1980'lerde Tuzluçayır." Kebikeç, 20: 201-211.

Sönmez, Mustafa (2011). Paran Kadar Sağlık: Türkiye'de Sağlığın Ticarileşmesi. İstanbul: Yordam.

Yeşilkaya, Neşe G. (2003). Halkevleri: İdeoloji ve Mimarlık. İstanbul: İletişim.

Yürekli, Yelda (2016). Küçük Moskova Tuzluçayır. İstanbul: İletişim. 